\title{
Міжнародна практика оцінювання якості життя населення літнього віку: систематизація та аналіз із позицій теорії соціальної держави
}

\begin{abstract}
Стаття присвячена аналізу світової практики оцінювання якості життя населення літнього віку у контексті прогресивних імперативів теорії соціальної держави. Аргументовано, щуо, серед іншого, в центрі уваги та структурі пріоритетів соціальної держави, як такої, що зорієнтована на виконання сочіально-захисних, стимулюючих, суспільно-інтегративних, соціальноінвестиційних функцій та функції соціального контролю, має перебувати зосередженість на проблематиці якості життя населення, зокрема прошарку населення літнього віку. Якість життя осіб літнього віку є одним із визначальних індикаторів успіхів та досягнень у розбудові сучасної сочіальної держави. Спираючись на узагальнені теоретичні та отримані за результатами проведеного дослідження емпіричні дані, зроблено висновки щьодо стану наближення України до реалізації засад конщепиї сочіальної держави, факт пріоритетності чого зафіксовано у Конституиії. Задля вирішення визначених завдань дослідження систематизовано та охарактеризовано міжнародні інтегральні індекси, щзо застосовуються в процесі визначення якості життя осіб літнього віку, зважаючи на сочіально-демографічні характеристики циільової аудиторії, специифіку науково-пошукових та прикладних задач, релевантних методичних підходів та джерел отримання даних. Авторами наведено результати систематизації та аналізу основних підходів щзодо оцінювання якості життя населення літнього віку, конкретизовано перспективи їх адаптації до вітчизняних реалій, зважаючи на особливості національної практики статистичних спостережень. Наведено та проаналізовано дані, опубліковані спеціалізованими установами Організації Об'єднаних Націй, Всесвітньої організаиії охорони здоров'я, Світового банку, Організації економічного співробітництва та розвитку, Свропейського Союзу, та дані міжнародних сочіологічних опитувань проєкту Gallup WorldView. Наголошено на необхідності розроблення підходів, які б забезпечували можливість зіставлення показників якості життя украӥнців з аналогічними показниками інших країн світу, щзо аргументує доцільність удосконалення вітчизняної практики статистичних спостережень $з$ метою створення інформаційно-діагностичної платформи, придатної для формулювання об'єктивних висновків стосовно якості життя в Украӥні, а відтак і ступеня ї̈ наближення до стандартів та еталонів держави соичіального типу.
\end{abstract}

Ключові слова: якість життя; населення літнього віку; оцінювання якості життя населення літнього віку; сочіальна держава; статистичне спостереження.

Постановка проблеми у загальному вигляді. Реалізація інноваційного сценарію суспільного розвитку та пріоритет розбудови України як соціальної держави передбачають необхідність створення умов для підвищення рівня та якості життя усіх верств населення. Зокрема, актуалізуються проблеми оцінювання якості життя населення літнього віку, що є важливим джерелом інформації для визначення цільових орієнтирів в управлінні економічними, соціальними та демографічними процесами. Впровадження у практику прогресивних методичних розробок, спроможних діагностувати та контролювати основні аспекти економічного і соціального благополуччя старшого покоління, необхідно розцінювати як важливу передумову поліпшення якості життя населення України.

Актуальність проблеми якості життя осіб літнього віку підтверджується ініціативами міжнародних організацій, насамперед ООН, урядами країн та експертними групами. Перша Всесвітня асамблея 3 проблем старіння населення відбулася у Відні у 1982 р. Підсумком роботи асамблеї став Міжнародний план дій $з$ питань старіння (МПДПС), рекомендації якого були спрямовані на реалізацію конституційних прав громадян літнього віку, запобігання виникненню можливих економічних та соціальних наслідків впливу небезпечних для здоров'я літніх людей факторів, створення оптимального середовища у сфері забезпечення їх життєдіяльності [1;2]. Втім, Міжнародний план дій з питань старіння, сформульований у другій половині XX ст., потребував уточнення, доповнення та конкретизації. На зустрічі представників урядів країн світу у Мадриді (2002р.) було представлено оновлений варіант цього документа, мета якого: поліпшення здоров'я, забезпечення інтеграції у суспільство, формування сприятливого навколишнього 
середовища та досягнення належного рівня матеріального добробуту задля гарантування найширших можливостей та свобод людей літнього віку. Перелік та зміст цих завдань свідчить про те, що поліпшення якості життя населення літнього віку дедалі більше стає стратегічною метою, на виконання якої наразі спрямовується політика соціально орієнтованих держав світу. Розвиваючи ідеї, зафіксовані у Міжнародному плані дій з питань старіння та інших міждержавних документах, фахівці Фонду ООН у сфері народонаселення спільно з урядами країн світу та незалежними експертами запропонували ряд методологічних підходів до вимірювання якості життя осіб літнього віку. Їх адаптація до реалій окремої країни потребує попередньої систематизації та предметного аналізу, що і визначило спрямованість проведеного авторами дослідження.

Аналіз останніх досліджень і публікацій. Світова наука пропонує низку підходів щодо оцінювання результативності державної політики у частині поліпшення якості життя населення літнього віку, які базуються на аналізі відповідних індикаторів у просторовому (міжрегіональному та міжкраїновому), статевому, часовому (ретроспективному чи прогнозному) розрізах. Таке оцінювання може бути проведене для літніх осіб з інвалідністю, для самотніх літніх осіб, для літніх осіб, які проживають у спеціалізованих закладах тощо. Разом з тим, практичне застосування тих чи інших підходів щодо оцінювання якості життя людей літнього віку почасти $є$ неможливим через відсутність достовірної інформації. I, як наслідок, широке коло питань, пов'язаних із проблематикою якості життя населення літнього віку, залишається малодослідженим, а відповідні завдання державної політики у частині розбудови держави соціального типу - нерозв'язаними. Тож, проблематику систематизації та аналізу існуючих підходів щодо оцінювання якості життя населення літнього віку слід вважати такою, що заслуговує на високу увагу як 3 боку вітчизняної, так і зарубіжної науки.

Значний внесок у розробку проблематики якості життя у розрізі демографічної структури населення в цілому та його літньої складової зокрема, зробили такі вчені, як С.Аксьонова, О.Гладун, В.Корчун, І.Курило, Е.Лібанова, О.Макарова, Л.Ткаченко, Н.Фойгт, Л.Черенько, Л.Шангіна, В.Юрчишин. Ними та іншими дослідниками проаналізовано поточну демографічну ситуацію, тенденції та наслідки старіння населення, пріоритети та інструменти поліпшення якості життя, розроблено рекомендації щодо забезпечення продуктивної суспільної взаємодії поколінь за умов депопуляції та глибокої трансформації вікової структури населення. У свою чергу, ідеї теорії соціальної держави проаналізовано та розвинуто у працях А.Колота, І.Лаврова, Е.Лібанової, Л.Лісогор, О.Палій та інших вітчизняних і зарубіжних вчених, вагомим науковим доробком яких стало уточнення змісту поняття «соціальна держава», конкретизація функцій соціальної держави та принципів її формування. Разом з тим, можна упевнено стверджувати, що через вплив різних об’єктивних та суб'єктивних факторів - проблематика якості життя населення літнього віку залишається для України такою, що потребує подальшого грунтовного опрацювання.

Метою дослідження $є$ систематизація та аналіз методичних підходів щодо оцінювання прогресу у забезпеченні високої якості життя населення літнього віку як ознаки та завдання соціальної держави.

Викладення основного матеріалу дослідження. До кінця минулого століття не існувало спеціальних узагальнюючих показників, які б давали змогу відображати та порівнювати умови життя людей у різних країнах світу. Найвідомішою та найбільш широко визнаною альтернативою ВВП став Індекс людського розвитку (Human Development Index). Результати обчислення Індексу та рейтинг країн, побудований за його значенням, публікуються у щорічному звіті ООН [3], починаючи з 1990 р. Прийнято вважати, що методика розрахунку Індексу людського розвитку (ІЛР) цілком репрезентативна для оцінювання якості життя населення, проведення міжрегіональних та міжкраїнових зіставлень, розроблення напрямів вдосконалення системи забезпечення життєдіяльності населення. ІЛР вимірює досягнення країни 3 точки зору стану здоров'я, рівня освіти та фактичного доходу іiі громадян за трьома основними напрямами, опосередкованими відповідними індексами. У 2010 р. перелік індикаторів, призначених для вимірювання ІЛР, було розширено, а сам індекс піддався істотному коригуванню: у соціально-економічну практику було введено Індекс людського розвитку, скоригований з урахуванням соціально-економічної нерівності (ІЛРН), Індекс гендерної нерівності (ІГН) та Індекс багатовимірної бідності (ІББ). Показник, який би охарактеризував становище населення літнього віку, розроблено не було. Натомість пошук шляхів удосконалення методології оцінювання якості життя населення призвів до розробки альтернативних соціально-економічних індексів. Серед них: Індекс процвітання Інституту Legatum (The Legatum Prosperity Index), Світовий індекс щастя (Нарpy Planet Index), Індекс кращого життя (Better Life Index) тощо [4-6]. Інновацією у розрахунку окремих індексів стало використання, окрім статистичних показників, даних актуальних соціологічних опитувань та експертних оцінок.

Обговорення стану реалізації МПДПС стимулювало міжнародний дискурс щодо розроблення підходів до вимірювання суспільного прогресу у сфері забезпечення якості життя населення літнього віку. Втім, наразі немає єдиного підходу до оцінювання якості життя населення літнього віку. Існуючу сукупність відповідних підходів систематизовано у таблиці 1. 
Таблиия 1

Загальна характеристика міжнародних систем оцінювання якості життя населення літнього віку

\begin{tabular}{|c|c|c|}
\hline Назва & $\begin{array}{c}\text { Кількість } \\
\text { охоплених країн }\end{array}$ & Характеристика \\
\hline Active Ageing Index & 28 країн СС & $\begin{array}{l}\text { Благополуччя осіб літнього віку та наявність } \\
\text { можливостей для активного довголіття }\end{array}$ \\
\hline Global AgeWatch Index & $\begin{array}{l}96 \text { країн, } \\
\text { у т. ч. Україна }\end{array}$ & $\begin{array}{l}\text { Якість життя осіб літнього віку та оцінка } \\
\text { ефективності державної політики у сфері } \\
\text { старіння }\end{array}$ \\
\hline $\begin{array}{l}\text { Hartford Index } \\
\text { of Ageing Societies }\end{array}$ & 18 країн ОЕСР & $\begin{array}{l}\text { Благополуччя осіб літнього віку та рівень } \\
\text { адаптації громадських інститутів до характеру } \\
\text { старіння }\end{array}$ \\
\hline $\begin{array}{c}\text { Global Aging } \\
\text { Preparedness Index }\end{array}$ & 20 країн & $\begin{array}{l}\text { Рівень адаптації громадських інститутів до } \\
\text { характеру старіння }\end{array}$ \\
\hline PwC Golden Age Index & 35 країн ОЕСР & $\begin{array}{lll}\text { Ступінь використання } & \text { продуктивних } & \text { сил } \\
\text { населення літнього віку } & & \\
\end{array}$ \\
\hline $\begin{array}{l}\text { Natixis Global } \\
\text { Retirement Index }\end{array}$ & $\begin{array}{c}43 \text { країни } \\
\text { (ОЕСР та БРІК) }\end{array}$ & $\begin{array}{l}\text { Оцінка матеріального добробуту осіб літнього } \\
\text { віку }\end{array}$ \\
\hline $\begin{array}{l}\text { Melbourne Mercer Global } \\
\text { Pension Index }\end{array}$ & 30 країн & Стійкість пенсійних систем \\
\hline
\end{tabular}

Згідно з першим підходом, розраховується Індекс активного довголіття (Active Ageing Index), який було запропоновано у 2012 р. [7]. Проєкт було реалізовано в межах Європейського року активного довголіття та солідарності поколінь під егідою Економічної комісії ООН (United Nations' Economic Commission for Europe, UNECE). Індекс активного довголіття - комплексний показник, який вимірює досягнення країни у сфері забезпечення умов для збереження високої працездатності та довголіття. Цільовими користувачами Індексу є політики та державні менеджери. На поточний момент цей індекс розрахований для 28 країн Європейського Союзу. Також ведуться роботи щодо його розрахунку для інших країн світу.

Для побудови Індексу активного довголіття використовуються 22 показники, об'єднані за такими напрямами: зайнятість; участь у суспільному житті; свобода, здоров’я та безпека; наявність умов для активного довголіття. Перші три групи показників вимірюють досягнення країни у сфері реалізації вимог людського розвитку. Четверта - вказує на можливість задоволення потреб людей прожити довге, здорове та продуктивне життя у даних соціально-економічних умовах. Вказана методологія передбачає конструювання індексів активного довголіття для різних вікових груп населення (50-59, 60-69, 70-74 років). Значення індексу варіює в межах від 0 до 100 балів. За результатами проведених досліджень, найбільш сприятливі умови для самореалізації, а також професійного та особистісного розвитку населення літнього віку, забезпечення його фізичного та психічного здоров'я демонструє Швеція.

Зміст поняття «активного довголіття» як наукової категорії було вперше представлено Всесвітньою організацією охорони здоров'я. Воно тісно пов'язане з якістю життя. Взаємозв'язок активного довголіття та якості життя полягає у тому, що якість життя - передумова, необхідна для досягнення основної мети: забезпечити довге, здорове та творче життя [8]. Міжнародним співтовариством наявність можливостей для реалізації принципів активного довголіття було визнано однією 3 головних характеристик рівня суспільного розвитку країни. Найважливішим досягненням розробників Індексу активного довголіття можна вважати створення доступної та порівнюваної бази даних для країн-членів ЄС, що сприяє кращому розумінню чинників впливу на якість життя населення літнього віку.

Розрахунок Індексу активного довголіття - не єдина методологічна розробка, яку запропонувала Економічна комісія ООН. Іншою такою розробкою є Рекомендації щодо статистики старіння населення, що сформовані на глобальному рівні. Рекомендації охоплюють 193 країни та визначають пріоритети змін у сфері надходження, обробки, збереження та розповсюдження відповідних статистичних даних [9, с. 233].

Відповідно до другого підходу, розраховується Global AgeWatch Index, що охоплює 96 країн світу [10]. Global AgeWatch Index вимірює досягнення країни з точки зору стану здоров'я, рівня освіти, професійної зайнятості, фактичного доходу, якості навколишнього середовища, в якому літні люди намагаються реалізувати свої можливості. На думку авторів проєкту, вказана методологія дозволить, по-перше, відстежувати зміни параметрів якості життя осіб літнього віку у процесі реалізації програм на національному рівні, а по-друге, виявляти міжрегіональні та міжкраїнові відмінності в якості життя літнього населення для визначення орієнтирів державної та регіональної соціально-економічної політики.

Global AgeWatch Index грунтується на статистичних даних різних міжнародних організацій. Зокрема, це Фонд ООН у сфері народонаселення (United Nations Population Department), Всесвітня організація 
охорони здоров'я (World Health Organization), Міжнародна організація праці (International Labour Organization), Світовий банк (World Bank), Міжнародний дослідний центр Геллапа (Gallup International).

Методологія розрахунку Індексу базується на мінімальному наборі індикаторів, за якими можна зібрати зіставні дані по кожній з країн. Для визначення рейтингу країни дослідження оцінює якість життя людей літнього віку за чотирма напрямами: матеріальне забезпечення, стан здоров'я, особистісний потенціал, сприятливе середовище, вимірювання яких опосередковане відповідними індикаторами (табл. 2). Ці величини стандартизуються у вигляді числових значень від 1 до 100, середнє арифметичне яких являє собою інтегральний показник Global AgeWatch Index. Значущість цих індикаторів враховується відповідно до ваг, які встановлюються на основі застосування коефіцієнтів багатофакторної регресії. Для цілей дослідження використовується принцип рівної значущості сфер людського життя [11].

Складовi Global AgeWatch Index

Таблиия 2

\begin{tabular}{|c|l|}
\hline Напрям & \multicolumn{1}{|c|}{ Індикатори } \\
\hline Матеріальне забезпечення & $\begin{array}{l}\text { Пенсійне забезпечення, рівень бідності осіб похилого віку, відносне } \\
\text { благополуччя осіб похилого віку, ВВП на душу населення }\end{array}$ \\
\hline Стан здоров'я & $\begin{array}{l}\text { Очікувана тривалість життя по досягненні 60-річного віку, очікувана } \\
\text { тривалість здорового житяя по досягненні 60-річного віку, психічне } \\
\text { здоров'я }\end{array}$ \\
\hline Особистісний потенціал & Зайнятість осіб похилого віку, рівень освіченості осіб похилого віку \\
\hline Сприятливе середовище & $\begin{array}{l}\text { Соціальні зв'язки, фізична безпека, громадянська свобода, } \\
\text { доступність громадського транспорту }\end{array}$ \\
\hline
\end{tabular}

У 2015 р. рейтинг за Global AgeWatch Index охоплював 96 країн. За загальною кількістю балів на першому місці опинилася Швейцарія (90,1 балів). Крім Швейцарії, рейтинг очолили Норвегія (89,3 бала), Швеція (84,4 бала), Німеччина (84,3 бала), Канада (84 бали). Україна посіла 73 місце зі значенням GAWI 37,0 (матеріальне забезпечення оцінено в 70,9 бала; стан здоров'я - 27,3 бала; особистісний потенціал 34,8 бала; сприятливе середовище - 54,8 бала). Порівняно 3 даними 2013 р. відбулося стрімке падіння вітчизняного рейтингу. Наразі Україна поступається за якістю життя людей похилого віку не лише країнам ОЕСР, Центральної та Східної Свропи, а й багатьом країнам Латинської Америки.

На Всесвітньому конгресі, організованому за участі Міжнародної асоціації геронтології та геріатрії у 2017 р., було представлено новий індекс, що вимірює рівень адаптації громадських інститутів до характеру старіння населення і пов'язаних з ним соціально-економічних змін. Індекс старіючого суспільства (The Hartford Index of Ageing Society) розроблений незалежними експертами Школи громадського здоров'я Мейлмана Колумбійського університету спільно з науковцями Центру економічної політики й охорони здоров'я Південної Каліфорнії за підтримки фонду імені Джона Хартфорда. Значення цього Індексу грунтується на 22 показниках, які для зручності об'єднані у п’ять груп: продуктивність та соціальне включення (рівень економічної та соціальної активності), благополуччя (стан здоров'я та задоволеність життям), рівність (депривації за доходами), згуртованість (міжпоколінні та соціальні зв'язки), безпека (пенсійне забезпечення та фізична безпека). Поряд з мікрорівневими характеристиками, у цій методології враховано окремі макрорівневі індикатори. Особливу увагу було приділено розрахунку коефіцієнта підтримки літніх людей.

Згідно з методологією Міжнародного центру перспективних досліджень, що входить до групи Глобальної ініціативи щодо проблем старіння, розраховується Індекс готовності до старіння (Global Aging Preparedness Index) для 20 країн світу [12]. Цей Індекс складається з двох окремих індексів: Індексу фінансової стійкості та Індексу добробуту, вимірювання яких опосередковане набором індикаторів. Перший визначається за коефіцієнтом демографічного навантаження особами літнього віку, рівнем залежності від державних пенсій та прогнозованим рівнем витрат на фінансування загальнообов'язкових програм і заходів соціального спрямування. Для розрахунку другого використовуються прогнози щодо змін у програмах пенсійного забезпечення, приватних пенсійних планах та спроможності літніх осіб активно працювати.

У свою чергу, PwC Golden Age Index розраховується щорічно для 35 країн ОЕСР міжнародною консалтинговою компанією PriceWaterhouseCoopers. Індекс відображає ступінь використання продуктивних сил населення літнього віку. Оцінка проводиться на основі даних за такими критеріями, як продуктивна зайнятість та освіта, а саме: рівень зайнятості осіб віком 55-64 роки, рівень зайнятості осіб віком 65-69 років, співвідношення зайнятих жінок та чоловіків віком 55-64 роки, частка неповної зайнятості серед осіб віком 55-64 роки, повна зайнятість 55-64-річних відносно 25-54-річних, середній ефективний вік виходу за межі ринку праці, освітня активність: відношення 55-64-річних до 25-54-річних. Натомість Global Retirement Index (GRI), запропонований Natixis Investment Managers i CoreData Research, 
відображає добробут осіб похилого віку з використанням 18 показників, які для зручності об’єднанні у 4 групи: здоров'я, пенсійне забезпечення, якість життя, матеріальний добробут. Natixis Investment Managers обробляє дані для 43 країн світу, що включають розвинені країни ОЕСР та країни БРІК [13; 14].

Melbourne Mercer Global Pension Index (Глобальний пенсійний індекс) використовується для оцінки якості пенсійних систем у 30 країнах світу. Індекс розраховується глобальною консалтинговою компанією Mercer спільно 3 Австралійським центром фінансових досліджень (ACFS) на основі офіційних статистичних даних. Melbourne Mercer Global Pension Index вимірює досягнення країни 3 точки зору достатності, стійкості та цілісності пенсійних систем за трьома основними напрямами, опосередкованими відповідними індексами (табл. 3) [15, с. 5]. Інтегральний індекс базується на трьох вказаних субіндексах. На підставі значення Melbourne Mercer Global Pension Index проводиться ранжування держав за рівнем стійкості пенсійних систем.

Таблиця 3

Складові Melbourne Mercer Global Pension Index

\begin{tabular}{|c|c|l|}
\hline Субіндекс & Вага & \multicolumn{1}{|c|}{ Індикатори } \\
\hline Достатність & $40 \%$ & $\begin{array}{l}\text { Виплати, дизайн системи, заощадження, податкова підтримка, володіння } \\
\text { житлом, активи зростання }\end{array}$ \\
\hline Стійкість & $35 \%$ & $\begin{array}{l}\text { Пенсійне покриття, загальні активи, пенсійні внески, демографічне } \\
\text { навантаження, державний борг, економічне зростання }\end{array}$ \\
\hline Цілісність & $25 \%$ & Регулювання, управління, захист, комунікація, витрати \\
\hline
\end{tabular}

Aegon Retirement Readiness Index (Індекс готовності до пенсії) заснований за результатами серії онлайнопитувань громадської думки. Дослідження розпочато у 2012 р. за ініціативою міжнародної страхової групи Aegon Group. Під час проведення опитування респонденти мають відповісти на низку запитань, зокрема: готовність нести особисту відповідальність за рівень пенсійних доходів; спроможність здійснити фінансове планування пенсійних надходжень; фінансова готовність до виходу за межі працездатного віку; рівень прогнозованого заміщення доходу. Також опитування спрямоване на оцінку ощадної поведінки осіб похилого віку. Відповідно до наданої експертами класифікації, пропонується диференціювати опитаних на п'ять груп за напрямами: особи, які заощаджують; особи, які випадково заощаджують; особи, які заощадили у минулому; особи, які прагнуть до заощаджень; особи, які не заощаджують [16]. Значення Індексу стандартизується у вигляді числових значень від 0 до 10.

Крім охарактеризованих вище методик, існують підходи щодо оцінювання якості життя населення літнього віку на рівні окремих країн. Зокрема, у США для поліпшення доступу до інформації стосовно населення літнього віку був створений Федеральний міжвідомчий форум зі статистики старіння, який об'єднує дані Національного інституту старіння, Національного центру статистики здоров'я й перепису населення, Бюро статистики ринку праці, Центрів послуг Medicare та Medicaid, Департаменту будівництва та міського розвитку та інших урядових інституцій [17]. Результатом його роботи є статистичний аналітичний звіт Older Americans: Key Indicators of Well Being. Основна мета складання звіту - відстеження динаміки демографічних, економічних та соціальних показників, поглиблення статистичних знань громадян та покращення рівня володіння статистичною інформацією державними менеджерами. В цілому система показників охоплює 41 ключовий індикатор, які згруповані за такими напрямами: населення, економіка, стан здоров'я, ризики здоров'я та поведінка, охорона здоров'я, середовище та оточення [18].

Інститут Мілкена та Центр майбутнього з проблем старіння, починаючи з 2012 р., щорічно складають рейтинг кращих міст США для успішного старіння (Best Cities for Successful Aging). Дослідження проводиться на основі даних за дев'ятьма основними напрямами, такими як комфортні умови життя, система охорони здоров'я, стан здоров'я, житлові умови, зайнятість, освіта, соціальні зв'язки. Ідеологічною основою рейтингу є концепція міста, комфортного для старіння (age-friendly city). Відповідно до визначення, запропонованого ВООЗ, це місто, у якому політика, послуги, оточення та структура дозволяють людям старіти активно [19, с. 5].

В цілому проведений аналіз засвідчив наявність різних - як за змістом індикаторів, так і за практикою застосування - методик, призначених для оцінювання якості життя населення літнього віку, придатних, при цьому, для використання в Україні з метою проведення міжнародних зіставлень. Втім, перспективи застосування вказаних методик знаходяться у прямій залежності від наявності зіставної статистичної бази, необхідної для проведення розрахунків.

Висновки та перспективи подальших досліджень. Наразі наукова спільнота проводить активну роботу у сфері розробки методів оцінювання якості життя осіб літнього віку, адже досягнення та підтримання належної якості життя цієї категорії населення є пріоритетним завданням країн світу, зорієнтованих на утвердження принципів соціальної справедливості та практичну реалізацію моделі соціальної держави. Спираючись на результати проведеного дослідження, автори вважають правомірним 
стверджувати, що, з одного боку, якість життя населення літнього віку виявляється у широті спектра тих можливостей, які цій категорії осіб надає суспільство, а з другого - у показниках психічного та фізичного здоров'я, що визначають спроможність цими можливостями скористатися. Відповідно, під поліпшенням якості життя осіб літнього віку доцільно розуміти розширення різноманітних побутових, соціальнокомунікативних, культурно-дозвільних та інших можливостей за одночасного створення умов для збереження, відновлення і розвитку їх фізичного та психічного здоров'я.

Якість життя населення літнього віку є однією $з$ детермінант наближення України до практичної реалізації моделі соціальної держави як такої, що, серед іншого, забезпечує однакові можливості для всіх членів суспільства, сприяє розвитку їх соціального потенціалу, визнає соціальні чинники важливою домінантою економічного прогресу, розвиває інститути соціального захисту, а реалізацію принципу активного довголіття розцінює як один з цільових орієнтирів державотворення. Зважаючи на викладене, до основних перспектив подальших досліджень у площині проблематики якості життя населення літнього віку в цілому та аналізу його показників зокрема, необхідно зарахувати створення адаптованої до вітчизняних реалій методологічної бази оцінювання, введення відповідних індикаторів до переліку досліджуваних Державною службою статистики України аспектів життя населення, що забезпечить наявність достовірної інформації, необхідної для науково-аналітичних узагальнень та подальшого розроблення дієвих заходів, спрямованих на поліпшення якості життя літніх людей.

\section{Список використаної літератури:}

1. Віденський Міжнародний план дій з проблем старіння : станом на 6 серпня 1982 р. / Документ ООН [Електронний ресурс]. - Режим доступу : https://zakon.rada.gov.ua/laws/show/995_870.

2. Мельничук Д.П. Модернізація системи управління закладами охорони здоров'я: аналіз проблеми 3 позицій поліпшення якості життя осіб літнього віку / Д.П. Мельничук, Л.І. Хом'як // Вчені записки Університету «КРОК». - К. : Університет «КРОК», 2018. - № 4 (52). - С. 156-163.

3. Human Development Report 1990. Concept and Measurement of Human Developmen / UNDP. - New York, 1991.$189 \mathrm{p}$.

4. The Legatum Prosperity Index [Електронний pecypc]. - Режим доступу : https://www.prosperity.com/.

5. Happy Planet Index [Електронний ресурс]. - Режим доступу: http://happyplanetindex.org/.

6. Better Life Index [Електронний ресурс]. - Режим доступу: http://www.oecdbetterlifeindex.org/ru/about/ru_whatsyour-better-life-index/.

7. Active Ageing Index [Електронний pecypc]. - 4 Режим доступу : http://www1.unece.org/stat/platform/display/AAI/Active+Ageing+Index+Home.

8. Мельничук Д.П. Людський капітал: пріоритети модернізації суспільства у контексті поліпшення якості життя населення : монографія / Д.П. Мельничук. - Житомир : Полісся, 2015. - 564 с.

9. Кірнос І.О. Міжнародні індекси старіння / І.О. Кірнос // Інфраструктура ринку. - № 21. - 2018. - С. $232-240$.

10. Global AgeWatch Index [Електронний ресурс]. - Режим доступу : https://www.helpage.org/global-agewatch/.

11. Вимірювання якості життя в Україні : аналітична доповідь / Е.М. Лібанова, О.М. Гладун, Л.С. Лісогор та ін.К. : ІДСД ім. М.В. Птухи, 2013. - 48 с.

12. Jackson R. The Global Aging Preparedness Index. Second edition / R.Jackson, N.Howe, T.Peter. - Washington : Center for strategic and international studies ; Jackson National Life Insurance Company, 2013. - 72 p.

13. PWC Golden Age Index. Unlocking potential \$ 3,5 trillion prize from longer working lives / PricewaterhouseCoopers LLP. - 2018.

14. 2017 Global Retirement Index. An in-depth assessment of retirement security in the developed world / Natixis Investment Managers Електронний ресурс]. - Режим доступу : https:// www.im.natixis.com/us/resources/2017global-retirementindex.

15. Melbourne Mercer Global Pension Index. - Australian Centre for Financial Studies ; Melbourne ; Mercer, 2017. $80 \mathrm{p}$.

16. Successful Retirement - Healthy Aging and Financial Security. The Aegon Retirement Readiness Survey 2017. Aegon [Електронний ресурс]. - Режим доступу : https https://www.aegon.com/siteassets/research/2017retirement-survey/retirementreadiness-survey-2017.pdf.

17. Agingstats.History of the forum [Електронний pecypc]. - Режим доступу: https:// agingstats.gov/about.html.

18. Older Americans 2016: Key Indicators of Well-Being / Federal Interagency Forum on Aging-Related Statistics. Washington, DC : U.S. Government Printing Office, August, 2016.

19. Global Age-friendly Cities : A Guide / World Health Organization. - Geneva, 2007. - 82 p.

\section{References:}

1. Videns'kyj Mizhnarodnyj plan dij $\mathrm{z}$ problem starinnja, [Online], available at: https://zakon.rada.gov.ua/laws/show/995_870

2. Mel'nychuk, D.P. and Hom'jak, L.I. (2018), «Modernizacija systemy upravlinnja zakladamy ohorony zdorov'ja: analiz problemy z pozycij polipshennja jakosti zhyttja osib litn'ogo viku», Vcheni zapysky Universytetu «KROK», No. 4 (52), pp. 156-163.

3. UNDP (1991), «Concept and Measurement of Human Developmen», Human Development Report 1990, New York, $189 \mathrm{p}$. 
4. The Legatum Prosperity Index, [Online], available at: https://www.prosperity.com/

5. Happy Planet Index, [Online], available at: http://happyplanetindex.org/

6. Better Life Index), [Online], available at: http://www.oecdbetterlifeindex.org/ru/about/ru_whats-your-better-life-index/

7. Active Ageing Index, [Online], available at: http://www1.unece.org/stat/platform/display/AAI/Active+Ageing+Index+Home

8. Mel'nychuk, D.P. (2015), Ljuds'kyj kapital: priorytety modernizacii' suspil'stva u konteksti polipshennja jakosti zhyttja naselennja, monografija, Polissja, Zhytomyr, 564 p.

9. Kirnos, I.O. (2018), «Mizhnarodni indeksy starinnja», Infrastruktura rynku, No. 21, pp. 232-240.

10. Global AgeWatch Index, [Online], available at: https://www.helpage.org/global-agewatch/

11. Libanova, E.M., Gladun, O.M., Lisogor, L.S. et al. (2013), Vymirjuvannja jakosti zhyttja v Ukrai'ni, analitychna dopovid', IDSD im. M.V. Ptuhy, Kyiv, 48 p.

12. Jackson, R., Howe, N. and Peter, T. (2013), The Global Aging Preparedness Index, Second edition, Center for strategic and international studies, Jackson National Life Insurance Company Washington, $72 \mathrm{p}$.

13. PWC (2018), PWC Golden Age Index. Unlocking potential \$3,5 trillion prize from longer working lives, PricewaterhouseCoopers LLP.

14. Natixis Investment Managers (2017), «Global Retirement Index. An in-depth assessment of retirement security in the developed world», [Online], available at: https:// www.im.natixis.com/us/resources/2017-global-retirementindex

15. Mercer (2017), Melbourne Mercer Global Pension Index, Australian Centre for Financial Studies, Melbourne, 80 p.

16. Aegon, «Successful Retirement - Healthy Aging and Financial Security. The Aegon Retirement Readiness Survey 2017», [Online], available at: https https://www.aegon.com/siteassets/research/2017-retirementsurvey/retirementreadiness-survey-2017.pdf

17. Agingstats.History of the forum, [Online], available at: https:// agingstats.gov/about.html

18. «Older Americans 2016: Key Indicators of Well-Being» (2016), Federal Interagency Forum on Aging-Related Statistics, U.S. Government Printing Office, Washington, DC.

19. World Health Organization (2007), Global Age-friendly Cities, A Guide, Geneva, 82 p.

Мельничук Дмитро Петрович - доктор економічних наук, доцент, професор кафедри психології та соціального забезпечення Державного університету «Житомирська політехніка».

https://orcid.org/0000-0002-9918-0608.

Наукові інтереси:

- соціальне забезпечення, соціальна та гуманітарна політика;

- психологія управління та HR-менеджмент.

E-mail: melndp@ukr.net.

Шпиталенко Галина Андріївна - кандидат історичних наук, доцент, доцент кафедри права та правоохоронної діяльності Державного університету «Житомирська політехніка».

Наукові інтереси:

- історія і теорія вітчизняних та зарубіжних державотворчих і правотворчих процесів;

- соціально-правова держава, громадянське суспільство.

E-mail: galina_s_08@ukr.net.

Тростенюк Тетяна Михайлівна - старший викладач кафедри економічної безпеки, публічного управління та адміністрування Державного університету «Житомирська політехніка».

https://orcid.org/0000-0001-7130-7454.

Наукові інтереси:

- управлінський облік в державних закладах вищої освіти;

- державне фінансове забезпечення.

E-mail: trost_taniash@ukr.net.

Хом'як Любов Ігорівна - аспірантка Інституту демографії та соціальних досліджень ім. М.В. Птухи НАН України.

https://orcid.org/0000-0002-4097-7894.

Наукові інтереси:

- демографія, соціальна та економічна політика;

- якість життя населення.

E-mail: 1yubovhomyak@ukr.net. 